\title{
Wood Waste Management: Sawdust as a Planting Media during the COVID-19 Pandemic at Sindangmekar Village, Dukupuntang Subdistrict, Cirebon District
}

\author{
Arie Ardiyanti Rufaedah ${ }^{1 *}$, Lili Amalia ${ }^{2}$,Rosalia Rahayu ${ }^{3}$ \\ ${ }^{1,2,3}$ Mahardika College of Health Sciences, Cirebon \\ E-mail:ardiyanti09@gmail.com
}

\author{
Submitted article Juni 5, 2021 \\ Reviewed article Augustus, 132021
}

Accepted article Augustus 15, 2021

\begin{abstract}
One of the growing industries in Indonesia is the woodworking industry. Wood waste is waste or parts of the wood that no longer has economic value but may still be used at different processes and times. The woodworking industry produces wood waste in $22 \%$ wood scraps, $8 \%$ wood chips, and $10 \%$ sawdust. The fundamental problem in the woodworking industry at Sindangmekar Village was the lack of understanding and practice in wood waste management. Through the socialization of wood waste management as planting media, community service aims to increase knowledge regarding wood waste management. In addition, it can improve practice to manage sawdust as a planting media. Furthermore, it has economic value and becomes one of the solutions to financial problems during the COVID-19 pandemic. The socialization presented materials related to wood waste management and practiced making planting media from sawdust. Thirty participants attended this activity. There was a significant increase in pre-and post-test scores after socialization. In conclusion, socialization regarding wood waste management increases knowledge levels in wood artisans and youth alliance at Sindangmekar Village. In addition, participants can manage wood sawdust as a planting medium. As a result, it can increase the selling value of wood waste, and the surrounding environment becomes clean and healthy.
\end{abstract}

Keywords: Wood; Waste management; Sawdust; Planting media

\section{INTRODUCTION}

Industrial waste is one of the crucial problems in the industrial era. The urgency of industrial waste management can cause environmental problems, either in solid, liquid, or other forms of waste. Therefore waste treatment must be carried out early when the production process occurs. Otherwise, the threat of pollution will be fatal (Nasir, Saputro and Handayani, 2016). One of the growing industries in Indonesia is the woodworking industry. Wood waste is waste or parts of the wood that no longer has economic value but may still be used at different processes and times. The woodworking industry produces wood waste in $22 \%$ wood scraps, $8 \%$ wood chips, and 10\% sawdust (Purwanto, 2011).

Sindagmekar Village, Dukuntang Subdistrict, Cirebon District is a central area of the woodworking industry, and most of the people work as wood craftsmen. The problems faced by wood craftsmen in Sindangmekar Village were similar to wood artisans in general. The fundamental problem was the lack of knowledge and awareness in waste management (Nasir, Saputro and Handayani, 2016). The low knowledge levels and understanding among them were getting more complicated during the COVID-19 pandemic. The COVID-19 pandemic has increased unemployment and had a significant impact on the economic status of the community. In addition, many people complain about restricted activities during the COVID-19 pandemic (Hanoatubun, 2020). Therefore, it is necessary to socialize wood waste management to woodworkers at Sindangmekar Village during the covid-19 pandemic. 
During the covid-19 pandemic, One of the changes in the social order regarding society activity is Work From Home (WFH) and Study From Home (SFH). As result of staying at home for a long time will undoubtedly foster a sense of boredom and cause stress, which can decrease the immunity system in the human body. So, it is necessary to fill the free time with positive things, one of which is gardening (Watrianthos et al., 2020). The increase in public enthusiasm for gardening during the COVID-19 pandemic has become an opportunity for wood artisans at Sindangmekar Village. However, wood artisans and the community at Sindangmekar village did not understand sawdust can be a planting medium. So, the training to make sawdust as a planting media in wood artisans is necessary. Wood sawdust can be a planting medium. It is an organic material naturally decomposed by microorganisms into simple compounds. Substances resulting from this decomposition are integrated into the soil, and the ground may be fertile because it contains many nutrients needed by plants (Nasution, 2016). Sawdust was chosen because of its light texture, so the roots will grow and develop faster. Sawdust has a high porosity (soil pore) level, but its density can still be adjusted to get a controllable porosity level by adjusting the ratio of water poured (Prasetyo, 2015). Socialization is the first step of the community empowerment program. The socialization process is very influential on the sustainability of the program. Several methods of socialization that can be carried out include 1) Direct socialization, which is carried out directly by the facilitator to the community. This method is most effective because the facilitator can perform the face-to-face activity and provide detailed explanations regarding the program. The process may reduce misunderstandings because the public gets information directly from the source. 2) Indirect socialization through intermediaries. This method is efficient but less effective because people do not get information directly from the facilitator.

In principle, socialization can be done anytime, anywhere, and not limited by time, place, and target. Therefore, socialization must be carried out correctly and adequately since this is the first step in determining the implementation of the following program (Hamid, 2018). The socialization of wood waste as a planting media at Sindangmekar village hopefully can increase the knowledge and practice in wood waste management among society at Sindangmekar Village. In addition, it may have economic value and become one of the community's solutions for financial problems during the COVID-19 pandemic.

\section{GENERAL DESCRIPTION OF THE COMMUNITY, PROBLEMS, AND TARGET SOLUTIONS}

\section{General Description}

Sindangmekar village is the center of the woodworking industry that has an essential effect in the woodworking industry in the Cirebon area. It was marked by many wood artisans, wood cutting factories, and material shops selling the equipment needed by woodworkers. Wood artisans at Sindangmekar village have been around since 1949. Sindangmekar Village has a substantial effect as a pioneer in establishing a thriving woodworking industry in Dukungpuntang District.

\section{Problem}

Most people at Sindangmekar Village work as farm laborers (51\%) because 55\% of Sindangmekar villages are rice fields, $10 \%$ are traders, and $9.6 \%$ are woodworkers. Thus, wood artisans play an essential role as a driving force for the economy in meeting the daily needs of the society in Sindangmekar village. The education levels of the people at Sindangmekar village are varied. Some are highly educated, and many have only graduated from elementary school and even dropped out.

The low level of education and the lack of public knowledge regarding wood waste management led to poor public awareness to utilize wood waste to have economic value. Sawdust can be used as a planting medium to reduce environmental pollution. The COVID-19 pandemic impacts people's activities wherein people are limited to be at home more often. As a result, gardening is becoming popular. Planting media using sawdust can be an excellent alternative solution in gardening. 


\section{Target Solutions}

Based on these conditions, the target solution in community service is socializing about the management of wood waste as a planting media during the COVID-19 pandemic at Sindangmekar Village. Thus, it may have economic value and become one of the community's solutions for financial problems during the COVID-19 pandemic. In addition, it can increase knowledge and practice in wood waste management.

\section{METHODS}

This community service was socializing wood waste as a planting media during the COVID-19 pandemic by direct socialization. The participants were wood craftsmen at Sindangmekar Village, represented by housewives as the Harapan Jati furniture craftsmen's cooperative members - a forum for building trust and establishing good relations between fellow artisans. In addition, the socialization also involved the youth alliance at Sindangmekar Village as participants. The youth alliance's involvement will hopefully increase awareness in the younger generation in using wood waste as a planting medium to create a clean and healthy environment. Thus, 30 participants attended the socialization with health protocols during the COVID-19 pandemic by performing social distancing, wearing masks, checking temperature, and washing hands before entering the room.

The socialization methods were counseling, practice, and assistance to participants. In brief, the socialization stages included preparation, implementation, monitoring, and evaluation. The preparation stage consisted of a meeting on community service implementation strategy, site surveys, permits for community service implementation, and infrastructure preparation.

Then, the implementation stage consisted of an opening session and an introduction by the authors and participants. The socialization activity began with assessing the knowledge levels in the participants regarding the management of wood waste through a pre-test. The pre-test results were made to determine the appropriate socialization method. The further activity was delivering materials related to wood waste management, including the definition, composition, sources, management, and utilization of wood waste. In addition, the following material was the use of sawdust as a planting medium. The material presentation applied two-way communication between participants and presenters through discussion or question-andanswer sessions. After material delivery, participants practiced making planting media from sawdust while the authors assisted them.

Next, the participants signed a joint commitment to protect and maintain the surrounding environment by utilizing and managing wood waste as a planting media to reduce environmental pollution. Plants make oxygen stocks will be more abundant, and the air can be fresh.

Community service activity ended with the post-test as an evaluation. The evaluation aimed to compare knowledge levels before and after the socialization regarding the management of wood waste as a planting medium. The authors monitored participants through cooperative management and youth alliance regarding wood waste management as a planting media.

\section{RESULTS AND DISCUSSION}

On Friday, January 29, 2021, this community service was held at the Sindangmekar Village Hall entitled "Management of Wood Waste as a Planting Media during the COVID-19 Pandemic". It was synergized with the Pentas Ning Latar performance organized by the Sindangmekar Village Youth Alliance. Based on the initial observation results, the Sindangmekar Village community did not utilize or manage waste from the woodworking industry. So far, they had only burned the wood waste due to low knowledge levels and lack of information regarding wood waste management.

Wood Waste Management: Sawdust as a Planting Media during the COVID-19 Pandemic at Sindangmekar Village, Dukupuntang Subdistrict, Cirebon District Arie Ardiyanti Rufaedah, Lili Amalia,Rosalia Rahayu 
Knowledge is the result of knowing, and this occurs after people have sensed particular objects. According to Saputra and Mulasari (2017), one factor influencing knowledge levels is access to information. Lack of information cause ineffective acts, attitudes, and beliefs. The more information obtained by a person, the better his understanding and knowledge will be. Before socialization, we evaluated knowledge levels regarding wood waste management in participants.

Table 1. Knowledge Levels before Community Servise

\begin{tabular}{lcc}
\hline Knowledge Levels & Frequency & Percentage (\%) \\
\hline High & 0 & 0.0 \\
Moderate & 13 & 43.3 \\
Low & 17 & 56.7 \\
Total & 30 & 100 \\
\hline
\end{tabular}

Table 1 describes that most participants had low knowledge levels (56.7\%). Low knowledge levels regarding wood waste management were due to the lack of information. So far, they had only received information regarding the business prospects of the woodworking industry. There was no socialization regarding wood waste management. In addition, The use of wood sawdust as a planting medium was still very rarely applied by the community.

Many people have failed to use wood waste as a planting medium due to a lack of knowledge and accuracy in methods and techniques (Wardani and Sari, 2017). Therefore, one of the efforts that can be performed is delivering information through socialization. Socialization is an essential part and a milestone in the success of community service activity. Factors influencing socialization are education, socioeconomic, customs, public trust, and availability of time (Fitrianingsih, 2018). Community service activity is oriented to changing the expected behavior, namely healthy behavior. As a result, the community will have the ability to recognize health problems faced by themselves, their families, and groups and how to improve their health. Knowledge is an essential domain to form actions in individuals. Knowledge-based behavior is better than behavior that is not based on knowledge (Notoatmodjo, 2017). In this study, there were increased knowledge levels after the socialization.

Table 2: Knowledge Levels after Socialization

\begin{tabular}{lcc}
\hline Knowledge Levels & Frequency & Percentage $(\%)$ \\
\hline High & 26 & 86.6 \\
Moderate & 4 & 13.3 \\
Low & 0 & 0 \\
Total & 30 & 100 \\
\hline
\end{tabular}

Table 2 reveals that most participants have high knowledge levels after socialization (86.6\%), and few have good knowledge levels (13.3\%). A significant increase in knowledge regarding wood waste management can be observed from the differences in pre-and post-test scores. Increased knowledge forms positive behavior in wood waste management, primarily using wood sawdust as a planting media.

During the socialization activity, the community also practiced making sawdust as a planting medium. We observed that participants enthusiastically did the practice. Using sawdust as a planting medium makes the soil in the pot not mix and harden. The ground will be loose, so it will be easy to move and absorb water and air so that the plants become fertile. A mixture of one-third of the soil and two-thirds of sawdust makes the potting mass lighter when removed (Prasetyo, 2015). Wood waste contains a source of nutrients that is better for plant growth than other media. Sawdust used as a planting media must be sterile, not contain pesticides or other toxic materials. The proper selection of wood can maintain the long-lasting use of planting medium (Wardani and Sari, 2017). The steps to make sawdust as planting media consist of: (1) Grind the wood waste to a powder. The powder must be finely textured so the water can enter more efficiently and wood waste can be mixed more easily. (2) Put powder or sawdust in the container for planting plants. The container can be a 
pot or another form that allows for growing plants. (3) Mix it with soil and compost. Sawdust itself is insufficient and does not have the fertilizing elements needed by plants. Therefore, the mixing needs to be done so that plants become more fertile. Then we can plant the seeds of the plants we want in the mixture. (4) Water it every day with the proper ratio. Watering plants and setting the porosity of the planting media needs to be done so that the planting media may not be dense. Setting the porosity of this planting media can be done using water. Wood waste management aims to create a product with economic value. Sawdust waste that was previously only burned becomes more valuable after being used as a planting medium. Economically, the use of wood waste as a planting medium can increase the selling value of wood waste.

\section{CONCLUSIONS AND RECOMMENDATION}

This paper concludes that socialization regarding wood waste management increases knowledge levels in wood artisans and youth alliance at Sindangmekar Village. In addition, participants can manage wood sawdust as a planting medium. As a result, it can increase the selling value of wood waste, and the surrounding environment becomes clean and healthy. Moreover, it may reduce environmental pollution.

\section{REFERENCES}

Fitrianingsih, I. N. (2018) 'Model pengembangan masyarakat melalui program KOTAKU/Kota Tanpa Kumuh: studi analisis di Desa Krajankulon, Kecamatan Kaliwungu, Kabupaten Kendal'.

Hamid, H. (2018) Manajemen Pemberdayaan Masyarakat. De La Macca:Makasar.

Hanoatubun, S. (2020) 'Dampak Covid-19 terhadap Prekonomian Indonesia', EduPsyCouns: Journal of Education, Psychology and Counseling, 2(1), pp. 146-153.

Nasir, M., Saputro, E. P. and Handayani, S. (2016) 'Manajemen pengelolaan limbah industri', Benefit: Jurnal Manajemen dan Bisnis, 19(2), pp. 143-149.

Nasution, J. (2016) 'Kandungan Karbohidrat dan Protein Jamur Tiram Putih (Pleurotus Ostreatus) Pada Media Tanam Serbuk Kayu Kemiri (Aleurites Moluccana) dan Serbuk Kayu Campuran', EKSAKTA: Jurnal Penelitian Dan Pembelajaran MIPA, 1(1).

Notoatmodjo, S. (2017) Ilmu Perilaku Kesehatan. Jakarta: Rineka Cipta.

Prasetyo, I. (2015) 'perbedaan Penggunaan Serbuk Gergaji dari Kayu Keras dan Kayu Lunak Sebagai Media Tanam Terhadap Pertumbuhan Jamur Tiram Putih (pleurotus ostreatus'.

Purwanto, D. (2011) 'Pembuatan balok dan papan dari limbah industri kayu', Journal of Industrial Research (Jurnal Riset Industri, 5(1).

Saputra, S. and Mulasari, S. A. (2017) 'Pengetahuan, Sikap, dan Perilaku Pengelolaan Sampah pada Karyawan di Kampus”, Jurnal Kesehatan Masyarakat, 11(1), pp. 22-27.

Sutarman, I. W. (2016) 'Pemanfaatan limbah industri pengolahan kayu di kota denpasar (studi kasus pada cv aditya', Penelitian Dan Aplikasi Sistem Dan Teknik Industri, 10(1), p. 182888.

Wardani, R. A. K. and Sari, D. P. (2017) 'Pemanfaatan Limbah Gergaji Kayu sebagai Media Tanam Jamur dan Kain Perca untuk Bahan Baku dalam Packaging Fung-Cube', Proceeding Biology Education Conference: Biology, Science, Enviromental, and Learning, 14(1), pp. 83-87.

Watrianthos, R. et al. (2020) 'Belajar dari Covid-19: Perspektif teknologi dan pertanian'. Yayasan Kita Menulis. 